\title{
A experiência da maternidade em uma família homoafetiva feminina'
}

\author{
The experience of motherhood in a female \\ same-sex parenting family
}

\author{
Ana Laura Moraes MARTINEZ \\ Valéria BARBIERI ${ }^{2}$
}

\begin{abstract}
Resumo
A família nuclear heterossexual tem como marca a atribuição das funções materna/paterna aliada ao sexo dos cuidadores. Arranjos familiares diferentes são vistos como exceção e considerados como fonte de psicopatologias. Embora haja predomínio das famílias heteroparentais, elas hoje dividem espaço com novas configurações, como as famílias homoparentais. O presente ensaio buscou compreender, por meio do método de estudo de caso, como se dá o desempenho da função materna em uma família homoparental feminina, composta pelas parceiras e pelo filho biológico de uma delas. Foi realizada uma entrevista com o casal em separado e aplicação de desenho da família com estórias. Com a criança, realizou-se uma sessão lúdica. Também houve uma entrevista familiar diagnóstica com o casal e a criança, e uma devolutiva. O material foi interpretado pelo referencial psicanalítico. Observou-se que a maternagem foi, em grande parte, desempenhada pela parceira e não pela mãe biológica.
\end{abstract}

Unitermos: Família. Maternidade. Paternidade. Psicanálise.

\begin{abstract}
In families with a heterosexually-based core, maternal and paternal functions are associated with the gender of the care-givers. Families of non-traditional orientation are usually seen as a source of psychopathologies. Even though the conventional, traditional arrangement is still prevalent, this arrangement has come to share its space and importance with new and questioning family configurations, among which one may quote same-sex parents. The present essay has attempted to understand, by way of case studies, the performance of the maternal function in a female same-sex parenting family, composed of a female couple in the role of parents and the biological child of one of them. For the purpose of this analysis, an interview was conducted with the couple, separately, followed by the use of the family drawing test. A game was devised to test the child. There was also a diagnostic family interview with the couple and with child, with feedback. The material was interpreted on the basis of psychoanalytical reference. It was observed that the maternal function was largely conducted by the other partner and not by the biological mother.
\end{abstract}

Uniterms: Family. Motherhood. Fatherhood. Psychoanalysis.

$\boldsymbol{\nabla \nabla} \boldsymbol{\nabla} \boldsymbol{\nabla}$

1 Artigo elaborado a partir do projeto de doutorado de A.L.M. MARTINEZ, intitulado "A maternagem e a paternagem em famílias homossexuais". Universidade de São Paulo, 2008.

2 Universidade de São Paulo, Faculdade de Filosofia, Ciências e Letras de Ribeirão Preto, Departamento de Psicologia e Educação. Av. Bandeirantes, 3900, Monte Alegre, 14040-901, Ribeirão Preto, SP, Brasil. Correspondência para/Correspondence to: A.L.M. MARTINEZ. E-mail: <contato@psicologiaribeiraopreto.com.br>. 
A experiência da maternidade é uma temática complexa, que envolve fatores biológicos, culturais, sociais e psicológicos. Em cada cultura e sociedade ela é significada de forma distinta, o que irá interferir decisivamente na vivência individual do que é ser mãe. De acordo com esse ponto de vista, Scavone (2001) afirma que a maternidade deve ser entendida como um fenômeno social.

A "invenção" da maternidade, tal como concebida na família moderna, data do final do século XVIII e início do século XIX, quando ocorreu um declínio do poder patriarcal e maior controle das mulheres sobre a criação e educação dos filhos (Guiddens, 1993). Com essa divisão sexual do trabalho, os homens eram responsáveis pela provisão financeira, e as mulheres pelos cuidados com a casa e a prole, o que fez despontar uma intensa valorização do sentimento de amor materno, naturalizado e explicado a partir de bases biológicas e instintivas. A esse fenômeno Badinter (1985) deu o nome de mito do amor materno. Diante dessa prerrogativa, mulheres que não viam na maternidade uma realização pessoal, ou ainda, mães que não nutriam sentimentos ternos por seus filhos eram vistas com maus olhos, já que estariam negando sua natureza procriadora.

A Psicologia e a Psicanálise do século XIX também contribuíram para esse discurso, enfocando a importância do vínculo afetivo mãe-bebê nos primeiros anos de vida como fundamentais para o desenvolvimento infantil saudável. Tal concepção, a despeito de seu caráter genuíno, acarretou muitas vezes uma idealização da figura da mãe na literatura psicológica.

Entretanto, a partir da segunda metade do século $X X$, algumas importantes mudanças sociais começaram a se esboçar no âmbito das famílias, até então fundamentadas no amor romântico. Com a consolidação da sociedade industrial, o conceito de maternidade sofreu alterações, passando de um modelo tradicional a um modelo moderno (maternidade como escolha e proles reduzidas). Essa mudança na concepção da maternidade ocorreu em função do ingresso da mulher no mercado de trabalho (embora marcado por desigualdades), de seu maior acesso à educação e profissionalização, e do avanço dos métodos contraceptivos e, mais recentemente, conceptivos (Scavone, 2001).

Desde então, a vivência da maternidade é constituída por uma colcha de retalhos, por possibilidades e paradoxos diversos, trazendo às mulheres pós-modernas algumas implicações e conflitos importantes. Conjugando múltiplos e variados papéis, as mulheres experimentam diversas possibilidades de existência e de pertencimento, o que, às vezes, é vivido com grande dose de angústia. As famílias também se reconfiguram de formas múltiplas e variadas, sendo cada vez maior o número de famílias recompostas, monoparentais, adotivas, homossexuais ${ }^{3}$ e homoparentais ${ }^{4}$. Com isso, a experiência da maternidade se modifica radicalmente e de diversas maneiras - mulheres que optam por não ter filhos, que buscam produções independentes através da inseminação artificial, por exemplo, ou ainda, homossexuais que buscam na ciência ou na adoção a possibilidade de viverem a maternidade (Roudinesco, 2003). Entretanto, apesar dessa diversidade vivencial referente à maternidade, ainda parece perdurar uma intensa representação que a associa à determinação biológica feminina, o que faz com que qualquer ação que contrarie tal lógica seja vista como perversa ou patológica.

\section{Maternidade e determinismo biológico}

Enquanto na Idade Média o reconhecimento da filiação se dava pela palavra do pater em relação ao filho, que podia ou não ser biológico, a partir da Idade Moderna começa a haver uma intensa valorização dos laços consanguíneos nesse reconhecimento (Lévi-Strauss, 1956), fazendo da célula familiar nuclear mãe, pai e filho - o lugar privilegiado para a construção do indivíduo. Essa "cultura do sangue e da biologia" acabou por enfatizar que a "preparação biológica" vivida pela mulher durante a gravidez implicaria uma prontidão para que ela vivenciasse de forma positiva a maternidade e o cuidado com o filho recém-nascido. Haveria, assim, um encantamento quase mágico e imediato de um pelo outro, o que poderia ser facilitado, segundo Durhan

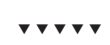

3 O termo homossexualidade indica a existência de prática sexual com pessoas do mesmo gênero, não implicando mudança de definição de sexo.

4 O termo homoparentalidade, criado na França em 1997 pela Associação de Pais e Futuros Pais Gays e Lésbicas (APGL), designa uma situação em que pelo 
(1983), por causa do longo período de tempo que a mãe passa gestando e cuidando do seu bebê. Winnicott (1964/1982) afirma, nesse sentido, que não era possível a ele saber o que sentia uma mãe ao ver seu filho no berço, já que esse "encantamento" era algo que só as mulheres podiam sentir.

Por conta desta concepção, mães que rejeitavam seus filhos no início da vida passaram a ser vistas como apresentando alguma doença séria, tal como Tristeza Materna, Psicose Puerperal e Depressão Pós-Parto (American Psychiatric Association, 1995), por negarem sua natureza afável e procriadora.

Contrariando a visão anterior presente em alguns momentos de sua obra, Winnicott (1964/1982) afirma que o desempenho da função materna não está restrito à mãe biológica. Ao contrário, muitos pais podem se mostrar melhores no desempenho dessa função do que as mães biológicas. O mesmo pode ocorrer com as mães adotivas que, oferecendo um ambiente de continuidade e de estabilidade ao bebê, podem vir a compensá-lo em relação ao seu início de vida e de amamentação, confuso e turbulento. Nesse sentido, Winnicott, sem negar as dificuldades enfrentadas pela criança logo no início da vida, considera que o bebê alimentado por mamadeira desde o princípio, embora mais pobre de experiência, ou talvez por causa disso, será capaz de ser alimentado por uma série de pessoas solícitas sem que isso Ihe provoque muita confusão. Essa afirmação é importante, pois desconstrói em parte a ideia de que toda criança adotiva estaria predisposta a desenvolver doenças do self pelo seu início de vida difícil e conturbado.

Dessa forma, nota-se que Winnicott oscila ao longo da sua obra entre duas posições relacionadas ao cuidado materno-infantil. A primeira, em que aponta uma associação entre a preparação biológica da mãe para o cuidado da criança, e a segunda, em que questiona a associação entre a biologia e a disposição afetiva para o cuidado e enfoca que pais ou mesmo mães adotivas podem exercer de forma bastante satisfatória a preocupação materna primária. Tal função, segundo o autor, pode ser realizada por qualquer pessoa capaz de: existir e continuar existindo, mesmo após os ataques do bebê; amar de um modo físico, proporcionando calor, contato corporal, movimento e quietude; auxiliar o bebê na transição entre o estado de tranquilidade e o de exci- tação; permitir que o bebê domine; introduzir aos poucos o mundo externo; fornecer continuidade ao bebê sem apressar seu desenvolvimento; e, por fim, tolerar sua falta de integração (Winnicott, 1964/1982).

Nesse último aspecto, a teoria winnicottiana parece deixar claro que o importante é que alguém disponível assuma o cuidado físico-afetivo da criança, quando a mãe se encontra impossibilitada de assumi-lo, seja por questões de ordem afetiva, material ou ambas. Esse argumento abre possibilidades para abarcar, em sua teoria, o desempenho da função materna em famílias que fogem ao modelo tradicional, tais como as modalidades homoparentais, que problematizam a associação entre a maternagem e a biologia.

\section{A família homoparental}

O termo homoparentalidade foi cunhado em 1997 pela Associação de Pais e Futuros Pais Gays e Lésbicas (APGL) em Paris, nomeando a situação em que pelo menos um adulto que se autodesigna homossexual é ou pretende ser pai ou mãe de, pelo menos, uma criança. Trata-se de um modelo familiar alternativo, que abrange os vínculos parentais entre homossexuais, travestis ou transexuais e seus possíveis filhos adotivos ou biológicos, no caso de filhos de casamentos ou relacionamentos heterossexuais anteriores (Zambrano, 2006).

As críticas a essa organização familiar são inúmeras, sendo a principal delas referente ao temor de que a criança que se desenvolve neste contexto tenha dificuldade para discriminar o feminino do masculino e de constituir sua própria sexualidade. Outro discurso que reforça tal visão diz respeito aos possíveis preconceitos que a criança irá sofrer na escola e na comunidade em geral (Uziel, 2002). De acordo com Zambrano (2006), tanto a escola como as pessoas em geral não estão preparadas para lidar com tal diversidade.

Porém, estudos já mostraram que crianças criadas por famílias homoparentais adquirem maior capacidade de transitar entre diferentes possibilidades de relações afetivo-sexuais, posicionando-se de forma mais aberta em relação a elas. Nesse contexto, Bailey, Bobrow, Wolf, Mikach (1995) revelaram que mais de 90\% dos filhos adultos de pais gays se consideravam heterossexuais. Stacey e Biblarz (2001) mostraram que a 
taxa de homossexualidade de meninos e meninas é igual em ambas as modalidades familiares, heterossexual e homoparental. Eles também revelaram que os filhos adolescentes de mães lésbicas tendem a ser menos agressivos que os das famílias heterossexuais; já as adolescentes tendem a se adaptar menos às expectativas tradicionais de sexo (docilidade, delicadeza etc.) e a ter um repertório maior de relações afetivo-sexuais.

Em relação ao modo como o casal homossexual vai desempenhar a função materna e paterna, ou seja, como será feita essa divisão em relação aos cuidados necessários à criança, Silverstein e Auerbach (1999) mostram uma tendência natural dessas famílias em desvincularem sexo e maternidade/paternidade. Assim, eles sugerem uma semelhança entre as famílias homoparentais e a organização familiar de outras culturas, em que a maternidade/paternidade está mais ligada a estratégias de adaptação a contextos específicos, podendo a função parental ser perfeitamente exercida por pessoas de qualquer sexo, ligadas ou não biologicamente à criança. Silverstein e Auerbach afirmam ainda que arranjos familiares diversos do tradicional se mostram competentes no cuidado e educação da criança, independentemente de sua orientação sexual. Portanto, o mais importante para o desenvolvimento emocional da criança seria a existência de, pelo menos, um responsável adulto capaz de manter com ela uma relação afetiva sólida e saudável.

Diante dessas considerações, o presente ensaio teve como objetivo conhecer, por meio do estudo de caso de uma família homoparental feminina, o modo como se estabelece e se desenvolve a função materna, de modo a contribuir para o enriquecimento do arcabouço teórico da Psicologia Clínica e do Desenvolvimento, tornando-as cada vez mais inclusivas.

\section{Método}

\section{Participantes}

Joana ${ }^{5}$ : tinha 42 anos e trabalhava durante o dia como auxiliar de enfermagem. À noite, fazia o segundo ano de um curso de nível técnico de enfermagem. Era viciada em jogos (bingo). Seus pais moravam em outro Estado, e ela não possuía nenhum parente próximo na cidade onde residia. Apesar de manter uma relação afetiva com Mônica há vinte anos, Joana mantinha esporadicamente relações extraconjugais homo e heterossexuais, sendo que em um desses encontros engravidou de Pedrinho. Isso ocorreu em um período em que estava rompido o relacionamento com Mônica.

Mônica: possuía 52 anos e trabalhava no mesmo local que Joana. Cursou até o ensino médio. Sua família também residia em outro Estado. $O$ único parente próximo era uma irmã que morava no mesmo terreno em que ela e Joana, mas que não sabia que ambas formavam um casal. Ao contrário de Joana, Mônica não mantinha relações com outras mulheres e alegava ter certeza de sua homossexualidade. No passado, Mônica fora viciada em bebidas e drogas. Assim que ficou sabendo da gravidez de Joana, propôs que ambas reatassem a relação, para que ela pudesse auxiliá-la na gravidez.

Pedrinho: tinha 9 anos e estava na quarta série. Era filho biológico de Joana e nunca conheceu o pai, embora sempre insistisse para que a mãe os apresentasse. Durante o dia, quando não estava na escola, era cuidado pela irmã de Mônica. À noite ficava com Mônica, enquanto Joana estudava. Ao término deste estudo, seu pai faleceu e, segundo o casal, o menino estava bastante revoltado com a mãe.

\section{Instrumentos e procedimentos}

Após explicitação dos objetivos do trabalho e assinatura do Termo de Consentimento Livre e Esclarecido (TCLE) por parte do casal, deu-se início ao processo investigativo que constou das etapas a seguir descritas.

Foram feitos entrevistas individuais com Joana e Mônica, em momentos separados, gravadas em fita cassete, com o consentimento de ambas. A ordem das entrevistas foi sugerida por Joana, sendo ela a primeira e Mônica a segunda. Ao final da entrevista com cada

178 Nomes fictícios. 
participante, foi realizada a aplicação do Procedimento de Desenhos da Família com Estórias (DF-E), conforme proposto por Trinca (1997). Nesse momento, o gravador foi desligado para não provocar maiores resistências na associação de ideias das participantes.

No segundo encontro, realizou-se sessão lúdica com Pedrinho.

No terceiro encontro, reuniram-se todos os membros da família, para a realização da Entrevista Familiar Diagnóstica (EFD), conforme proposto por Soifer (1982). Nesse dia, utilizando como mediador a caixa lúdica (a mesma utilizada com Pedrinho), solicitou-se que eles brincassem como desejassem, enquanto eram observados pela psicóloga.

Por fim, foram marcados mais três encontros em dias separados, quando foram realizadas as devolutivas com Joana, Mônica e Pedrinho, bem como feitos os devidos encaminhamentos do caso. Exceto no momento das entrevistas semiestruturadas realizadas com Joana e Mônica, não foram empregados procedimentos de gravação dos encontros, sendo todos eles transcritos a posteriori, com exceção da aplicação do DF-E, quando a pesquisadora tomou nota das estórias no momento em que os participantes as produziam.

Utilizou-se como método de análise dos dados o referencial teórico da Psicanálise. Nessa modalidade de pesquisa qualitativa, compreende-se o investigador como parte integrante e fundamental na interpretação dos dados, através das modalidades de comunicação inconsciente que permeiam o campo, e que são fundamentais para a compreensão da dinâmica inconsciente dos participantes investigados.

\section{Resultados}

\section{Entrevista com Joana}

A gravidez de Joana ocorreu num momento em que estava separada de Mônica porque, segundo ela, a relação já tinha acabado há muito tempo. Contou que Mônica, ao saber da gravidez, propôs-se a ajudá-la a cuidar do bebê. Joana narrou que a gravidez, porém, afastou ainda mais as duas, particularmente na esfera sexual, embora tenha servido para uni-las afetivamente, já que agora tinham um bebê para cuidar. Joana viveu a gravidez invadida por sentimentos de rejeição e vergonha da barriga. Segundo ela, a rejeição da gravidez se deu porque também ela fora rejeitada pela mãe quando estava grávida dela. Era a filha mais nova de um casamento bastante conturbado, sendo que sua mãe estava com quarenta anos quando engravidou dela e já havia adotado um menino dez anos antes porque até então não tivera nenhum filho homem. Seu pai, por sua vez, era ausente mulherengo e passava vários meses viajando porque era caminhoneiro. Quando chegava em casa, apesar de trazer presentes para Joana (os quais ela esperava sempre ansiosamente), batia nela e na mãe e se embebedava. De acordo com Joana, tudo isso interferiu na vivência de sua gravidez, fazendo-a sentir pavor de engravidar.

Sua rejeição à gravidez estendeu-se depois do parto, interferindo na sua relação de cuidado com o filho. Assim, contou que grande parte do cuidado do filho foi assumido por Mônica, que Ihe dava banho, levava-o aos médicos e embalava-o nos momentos de choro. Por isso, considera-se mais pai do que mãe, tendo somente parido a criança. Em outros momentos, revelou que gostaria de ser uma mãe melhor e que às vezes se arrepende de perder a cabeça com o filho. Joana contou que, à noite, quando Pedrinho está com medo ou precisa de alguma coisa, procura Mônica e não ela. Também disse que, quando Mônica sai, Pedrinho fica apavorado com medo de ela não voltar mais.

\section{Entrevista com Mônica}

Em relação à gravidez de Joana, Mônica contou que esta ocorrera num momento em que elas estavam separadas e que, a princípio, foi um choque para ela. Entretanto, depois de dois dias já havia aceitado o fato e ligou para Joana oferecendo ajuda para cuidar da criança. A partir desse instante, começaram a morar juntas e não se separam mais, pelo menos fisicamente. Mônica disse também que, após o nascimento de Pedrinho, a relação sexual entre as duas esfriou, porque ela própria sentia estar desrespeitando a criança (mesmo se o encontro fosse fora da casa). Por outro lado, elas se aproximaram mais afetivamente. Nesse aspecto, Mônica disse se sentir confusa já que muitas vezes se questiona se continua na relação por causa de Joana ou de Pedrinho. Contou ainda que todas as vezes que elas saem sozinhas 
acabam falando dele e retornam rapidamente para casa, pois não conseguem ficar longe.

No que se refere ao cuidado de Pedrinho, comentou que assumiu grande parte das tarefas, uma vez que Joana voltou a trabalharcedo. Assim, ela era responsável por dar banhos, trocar fralda, levar aos médicos e embalar durante o choro. Contou que essa "divisão de tarefas" ocorreu de forma natural, já que Joana era meio sem paciência. Ressaltou que seu cuidado com Pedrinho não tem a ver com sua relação com Joana, ou seja, não faz isso como uma troca, mas sim porque tem um carinho enorme por ele. Narrou que Pedrinho, à medida que crescia, só queria ficar com ela e que, se ameaçasse sair de casa sozinha, ele abria um berreiro. O mesmo não acontecia com a mãe. Assim, muitas vezes, ela voltava mais cedo dos lugares para fazê-lo dormir, enquanto Joana continuava na festa. Ou então, ela emprestava o carro para Joana sair e ficava cuidando de Pedrinho. Contou que estimula Joana a sair mais vezes sozinha com o menino, mas que ela logo perde a paciência por serenérgica e inflexível com ele. Contou que, nos momentos de dormir, o menino a procura.

Em relação ao pai de Pedrinho, ressaltou não concordar com o fato de Joana nunca tê-lo apresentado à criança e disse temer por saber que, na adolescência, esse encontro será ainda mais delicado. Por outro lado, contou que Joana tem um medo intenso de tocar nesse assunto, e que só conseguiu conversar sobre isso com ela quando Pedrinho tinha quatro anos de idade. Já Pedrinho, segundo conta, evita tocar no assunto do pai quando ela busca conversar a respeito. Por fim, salientou que procura não se meter neste assunto, pois não Ihe diz respeito.

\section{Sessão lúdica com Pedrinho}

\section{0}

Pedrinho chegou para a sessão lúdica meio tímido, mas com um olhar muito curioso. Sozinho com a psicóloga na sala lúdica, o garoto pareceu mais à vontade. A psicóloga convidou-o a sentar-se, apresentou-se e mostrou-lhe a caixa, dela retirando o fantoche do Chapeuzinho Vermelho. Pedrinho parecia pisar em ovos. A psicóloga pegou o fantoche do lobo mau e, junto com Pedrinho, ensaiou uma pequena cena em que o lobo devorava Chapeuzinho. Pedrinho abandonou o fantoche de Chapeuzinho, meio assustado com o possível desfecho da história. Pegou miniaturas de soldados, monstros, cowboys e dinossauros, olhando-as atentamente e guardando com cuidado cada uma no devido lugar. Curioso com um carrinho de madeira, perguntou à psicóloga se ela o havia feito. Depois, curioso com a família de bonecos, repetiu a mesma pergunta, parecendo questionar se ela conseguia mesmo criar coisas. Encorajado pela psicóloga, abriu o saquinho com os bonecos e ficou surpreso e feliz ao encontrar o boneco-cachorrinho. Ensaiou novamente um mergulho na brincadeira, mas desistiu, guardando cuidadosamente a família. Isso tudo ainda parecia perigoso demais para ele. Voltou a pegar as miniaturas e, questionado se queria brincar com elas, balançou a cabeça em sinal positivo. Montou uma guerra entre monstros e soldados, cada um deles com um dinossauro guardião que os ajudava na luta. A guerra terminou com destruição e morte: os monstros mataram os soldados, os dinossauros mataram os monstros, um dinossauro matou o outro, restando apenas um, que morreu de fome e sede. Até mesmo a árvore miniatura morreu, porque ninguém se lembrou de colocar água nela.

A psicóloga começou a compreender por que Pedrinho esteve evitando, até aquele momento, mergulhar em alguma atividade lúdica - para não entrar em contato com as cenas de terror que moravam em sua mente. Tendo-Ihe a psicóloga dito que aquela era uma história muito triste porque tudo ficava destruído e solitário, Pedrinho balançou a cabeça em sinal positivo.

Notando que a vovó-boneco havia sido "esquecida" dentro do caminhão de madeira pela psicóloga, ele disse: "Nossa, esqueceram a vovó. A família toda dela foi viajar! Agora ela vai viajar também". Começou a locomover o caminhão, porém a vovó caiu várias vezes ao chão e foi atropelada por outro carro. A cena se repetiu algumas vezes e ela teve que ir para o hospital, onde ficou internada. A família foi visitá-la, mas só adultos podiam entrar no quarto; crianças e cachorros deviam ficar do lado de fora. Porém, o menino-boneco era esperto e deu um jeitinho de entrar. Ao ir embora, a família também sofreu um acidente e todos tiveram que voltar ao hospital, agora para ser internados. Ao receberem alta, foram para casa.

Nesse novo cenário, o menino e o cachorro eram grandes amigos e foram viajar (somente os dois) para 
vários países diferentes. O pai do menino não gostava do cachorro porque ele era de rua e tinha sarna. Por isso, seu pai tinha alergia a ele. Depois de uma viagem, o cachorro raivoso avançou contra o pai do garoto, que foi parar no hospital.

Em outro momento, o pai deu dinheiro para o menino comprar um cachorro de raça. Ele comprou um labrador, mas isso de nada adiantou, pois ainda assim o pai tinha alergia ao animal. Novamente, o menino e o cão foram obrigados a viajar, pois não havia lugar para eles ali. O boneco-bebê, que até então estava caído no chão (Pedrinho não o tinha manuseado ainda), foi enviado pelo correio pela mãe até o local onde o menino e o cachorro estavam. Nesse instante, a psicóloga disse a Pedrinho que era difícil para aquele menininho ter que cuidar de todos: do cachorro e do bebê. Ele respondeu: "A família dele é louca. Mas ele é forte". Voltando da viagem, o garoto fica"babando" pela moto, muito bonita, que o havia comprado. O cachorro foi enxotado novamente e ficou embaixo do carro. Então Pedrinho falou: "E assim termina a história. O menino cresce e vai trabalhar e o cachorro vira cão de guarda. Fica forte também!" Pôs o bebê em cima do carro, dizendo que o haviam esquecido lá, e colocou o cachorro guardando o bebê.

\section{Entrevista familiar diagnóstica}

Pedrinho, Joana, Mônica e a irmã desta chegaram ao consultório com cinco minutos de atraso. Chamados à sala de atendimento, todos se levantaram, exceto a irmã de Mônica que, segundo Joana, iria ficar cuidando das bolsas. Pedrinho subiu as escadas olhando atentamente para a mãe, mas, ao entrar pela porta do consultório, foi até a caixa de um jeito bem espontâneo. Joana sentou-se no divã e pegou o jogo UNO. Mônica ficou em pé, parada no meio da sala, parecendo sem lugar.

Pedrinho pegou o jogo de palitos e chamou Mônica para jogar, sentando-se ambos no chão. Nesse momento, Joana ficou visivelmente incomodada e permaneceu olhando para a caixa do UNO e para os dois jogando palitos. Depois, foi até a caixa, pegou o dominó, sentou-se ao lado deles e chamou Pedrinho para jogar, num tom sutilmente agressivo. Pedrinho foi imediatamente até a mãe, deixando Mônica no meio do jogo, desconcertada. Joana falou com Pedrinho de maneira agressiva: "Vai, pega a carta! Não tá vendo?".

Pedrinho abandonou o jogo, dizendo à mãe: "Mãe, essa é a família de bonecos que eu te falei!" Começou a tirar os bonecos do saquinho, pegando o menino e o cachorro. Joana perguntou quem eram, e Pedrinho respondeu ser Pipoca (sua cachorra), dando risada. Quando ele perguntou à mãe quem ela iria ser, ela primeiro pegou a menina (boneco que deveria ser irmã do menino-boneco), depois a avó, e ainda depois a boneca-adulta (segunda geração). Mônica, por sua vez, pegou a boneca-avó.

Pedrinho disse que o menino e o cachorro iriam viajar. Nesse momento, Joana ficou visivelmente angustiada e disse que ele não cabia naquele carro. Arrancou o boneco de dentro do carrinho, mas Pedrinho voltou a colocá-lo, dizendo que iriam viajar pelo mundo e não voltariam mais, porque ganharam na loteria. Joana perguntou: "Mas você vai sozinho? Não vai me levar junto? Duvido que consiga ir sozinho. Não consegue nem ficar à noite em casa sozinho. Tem medo de tudo" Esse diálogo se repetiu por alguns instantes. Depois, Pedrinho deu o bebê nos braços do boneco-mãe (Joana), dizendo: "Você se esqueceu do bebê." Ela disse: "Não. A mãe não quer o bebê", e colocou-o de lado. Joana pegou o fantoche de Chapeuzinho Vermelho, dizendo que ele não iria viajar porque morria de medo de ficar sozinho. Pedrinho pegou o fantoche de lobo mau, dizendo que, se ela não ficasse quieta, iria comê-la. Começaram a brigar com os fantoches.

Depois, Pedrinho pegou o papel e fez dois desenhos, o primeiro, um caçador tentando pegar um pica-pau arteiro, e o segundo, um homem das cavernas conversando com um caçador. Neste instante, Joana e Mônica diziam para Pedrinho tomar cuidado para não sujar a sala com as pontas de lápis. Minutos depois, Mônica pegou o boneco-vovó e colocou-o no carro, dizendo que iria dar uma voltinha. Pedrinho, com o fantoche de lobo mau, disse bravo que ela não iria a lugar nenhum, porque ela podia ir e não voltar mais. Disse ainda: "Se ela for, eu mato ela!". Mônica disse que só iria dar uma voltinha, que não iria embora para sempre. Então Joana disse: "Mas e se a vovó arrumar um namorado?" Pedrinho gritou: "Não quero". Mônica disse, tentando acalmá-lo: "Mas eu não vou embora. Vou ficar aqui". Por fim, Pedrinho disse: "Cansei, vou matar a tia 
Mônica". Pegou a espada de dentro da caixa, Joana pegou a outra e ambos começaram a lutar. Ganharia quem acertasse o coração do adversário. Joana quase acertou de verdade o olho de Pedrinho.

\section{Discussão dos Resultados}

\section{As experiências de rejeição}

Joana narrou sua experiência como mãe, esboçando a rejeição que sentiu pelo bebê já durante a gravidez. Racionalizou esse sentimento, explicando-o pela rejeição que ela própria sofrera quando a mãe se descobrira grávida dela, e pela relação tumultuada que os pais tinham. Essa experiência afetiva sinaliza que Joana, ao engravidar, reviveu de forma intensa e regressiva sentimentos experimentados pela mãe em relação a ela nos primeiros anos de sua vida, e que parecem ter comprometido seu desenvolvimento emocional.

Conforme assevera Winnicott (1988), a experiência da ilusão, a partir da qual o bebê acredita que cria o seio que lhe é apresentado pela mãe, é fundamental para a construção de um sentimento de existir no mundo de forma autêntica e integrada, o que Joana pareceu não conseguir sentir. Assim, ela permaneceu encarcerada numa dinâmica psicológica cujas origens parecem situadas numa insuficiência no suprimento de suas próprias necessidades de ilusão.

Buscando a reparação dessa falta, ela voltou-se para o pai, buscando nele continência e acolhimento que não recebeu da mãe; contudo sua empreitada foi novamente frustrada, dado que, em seu ponto de vista, o pai também não era uma pessoa digna de confiança, dada sua instabilidade afetiva. Com isso, Joana pareceu ficar dividida entre a mãe e o pai, sem vincular-se de forma segura a ninguém, podendo-se situar aí possivelmente a raiz de sua bissexualidade.

Como a ilusão não se completa, as introjeções não são possíveis, o que a deixa muito dependente do objeto externo, tal como fica em relação a Pedrinho. Ou seja, como não foi possível haver a introjeção segura de um objeto, necessita do objeto real para poder se acalmar e sentir que, de fato, ele existe. Nesse sentido,

182 Giovacchini (1995), aponta que as falhas na formação de representações mentais dos objetos, bem como a existência de um ego pouco integrado, que não consegue discriminar ou discrimina mal a realidade externa e interna, podem ser descritas como um quadro borderline. Nesses casos, conforme coloca o autor, a realidade externa é sentida como aniquiladora e invasora. No caso de Joana, tanto a realidade como o objeto externo ficam preenchidos de seus terrores e angústias, o que se expressa nos momentos em que busca se fundir a Pedrinho ou, então, nos momentos em que o repele para longe, quando percebe sua dependência extrema em relação a ele.

Essa relação ambivalente fica evidente no contato com Pedrinho, marcado ora por momentos de proximidade e indiscriminação, ora por momentos de rechaço e raiva, tal como expresso nos trechos a seguir:

Éque... o Pedrinhoéessa coisa assim tão boa que a gente acaba se cobrando. Tá bom aqui, mas tá na hora de ir embora que ele estálá sozinho. Coitadinho do Pedrinho. Fica vitimando ele. Ah, então vamos. Sempreque a gente sai pra beber: Ah, vamos. Mas quando o Pedrinho não está parece que falta um pedaço. Entende? Então fica aquele vazio, aquela coisa meio oca, sabe? Ás vezes ele está enchendo o saco: ah, ah, ah... Mas ele está.

Quando eu chego cansada ele quer falar tudo de uma vez, sabe? Eaíeuestou cansada. Tipo assim:eu tenho que tomar banho eele estájogando futebol. Aíeu brigo porque ele estájogando futebol e eu saio daqui sem ver ele. Então eu vou correndo chamar no futebol. Aí eu já venho brigando com ele. Aíeu já fico nervosa com ele, quero que ele tome banho, quero que coisa, porque eu estou indo praescola. Nessas horas eu acabo sentando a mão nele. Aí eu chego à escola e, mais tarde, eu fico ligando: Oh, filho, mamãe te ama. Isso aí eu falo pra ele todos os dias. Eu faço estas coisas porque eu te amo. Não quero que vocêfique na rua. Não gosto de criança que fica na rua.

Neste movimento confuso de indiscriminação e rechaço que Joana mantém com Pedrinho, observa-se que ele não consegue alcançar no vínculo com ela a segurança e a continuidade necessárias para se desenvolver, embora se mantenha bastante apegado a ela. A única figura que confere a ele segurança e alguma continência é tia Mônica, a quem Pedrinho se apega com mais confiança. A proximidade entre os dois provoca muito ciúme e raiva em Joana, que, em alguns momentos, chega a rivalizar a atenção de Pedrinho com Mônica, como observado no trecho descrito da Entre- 
vista Familiar Diagnóstica, em que ele decide jogar palitos com Mônica, e precisa deixar essa atividade porque Joana praticamente exige que ele venha jogar dominó com ela.

Essa situação coloca Pedrinho numa posição delicada - a de permanecer atento aos movimentos da mãe, sem, entretanto, se descuidar para que a tia Mônica não o deixe, o que lhe provoca bastante tensão e o impede de viver com autenticidade seus desejos amorosos e hostis. Com isso, ele procura se adequar ao ambiente para ser querido, mas, mesmo assim, teme provocar alergia (rejeição) nas pessoas de quem busca o afeto, como foi explicitado na sessão lúdica, no episódio de que faziam parte o menino, o pai e o cachorro.

Nesse momento também fica evidente como Pedrinho fica à mercê de seus impulsos destrutivos não simbolizados: o cachorro avança no pai por causa da sua raiva, o que o faz ir para o hospital.

Nessa configuração familiar em particular, Joana ocupa o lugar de pai, e não de mãe, contrariando o discurso biologicista de que mãe é aquela que pare:

Às vezes eu brinco que eu falo que eu só pari. Mãe mesmo é ela. Ele só dorme se for com ela. Tudo ele fica: Oh, tia Mônica." Que ele chama ela de tia.... Então émuito mais assim (silêncio). Eu sou o paizão, né. O pai de brigar, de xingar, de dar bronca. Ela não. Tudo o menino tá certo. Ai, coitado do menino, né. Sempre. Eu acho que aífica mais difícil ainda, né, dessa relação acabar porque o Pedrinho émuito dependente dela. Aonde vai, ela tem que ir junto. Hoje mesmo ela falou assim: "Vocêprecisa sair mais com a sua mãe, ficar mais sua mãe, né." Mas não. Ele tem que estar sempre... Saimais com ela mesmo do que comigo (silêncio).

Nesse sentido, Granato (2000) aponta que nem todas as mães biológicas conseguem viver de forma satisfatória a preocupação materna primária, com é o caso de Joana. Algumas temem que o estado de preocupação com seu bebê as deixe exauridas e, por isso, preferem entregá-lo aos cuidados de outro, voltando rapidamente aos seus afazeres costumeiros. No caso de Joana, segundo ela própria relata, logo após o parto retomou suas atividades profissionais rapidamente, deixando os cuidados do bebê com Mônica, embora fosse invadida com frequência por sentimento de culpa.

Essa necessidade de retomar suas atividades logo após o parto permite pensar que Joana fazia uso de seus elementos masculinos, tal como Winnicott (1975) concebe, para evitar mergulhar na regressão possibilitada pela gravidez. Assim, segundo ele, o eu, independentemente de ser homem ou mulher, conta com elementos masculinos e femininos que integram o self de forma mais ou menos equilibrada. No caso de Joana, o fazer (associado ao elemento masculino) parece predominar em sua conduta.

Já para Mônica, Pedrinho parece dar um novo sentido à sua vida. Oferecendo-se como um continente mais seguro a ele, ela capta a angústia do menino nos momentos de separação. Nesse sentido, pode-se afirmar que Pedrinho também permanece dependente do objeto externo para poder se acalmar, vivenciando uma experiência catastrófica ao menor sinal de ausência deste, uma vez que ele não pôde ser introjetado de forma satisfatória, tal como representado na entrevista familiar diagnóstica:

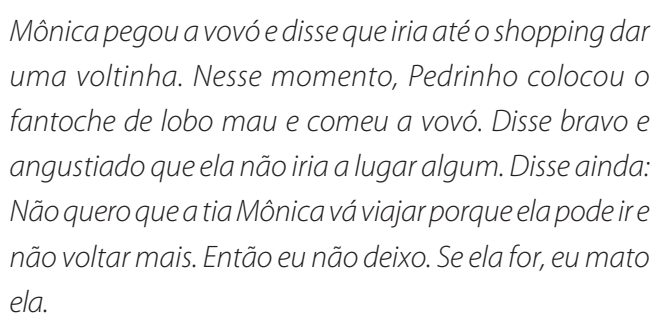

Essa vivência de extrema dependência do objeto parece repetir a história que Joana tem com seus objetos de apego, tornando o crescimento e o desenvolvimento emocional de Pedrinho ainda mais difícil.

\section{Mãe biológica e de coração}

Retomando os conceitos de Winnicott(1958/1983) acerca da importância da continência materna diante dos conteúdos primitivos do bebê recém-chegado, pode-se supor que Joana não consegue provê-lo de suficientes oportunidades de ilusão, em função de ela própria não ter tido devidamente atendidas as mesmas necessidades. Com isso, o contato com o meio e o olhar humanizador da mãe só Ihe foram possíveis até certo ponto. Daí sua dificuldade em se oferecer como continente mental e psíquico a Pedrinho, o que torna os impulsos vivenciados por Pedrinho perigosos e mortíferos, já que não puderam ser humanizados. Com isso, diante da ausência de um continente que possa digerir sua agressividade não metabolizada, ela se torna bastante perigosa. 
Diante da dificuldade que Joana apresenta para conter e metabolizar as angústias do filho e permanecer viva para ele, Mônica ocupa esse papel de cuidadora, acolhendo suas angústias e, com isso, Pedrinho se torna muito apegado a ela. Essa dinâmica familiar vem corroborar a ideia, já bastante difundida na Sociologia e na Antropologia, de que a preparação gestacional vivida pela mulher não constitui necessariamente uma preparação emocional para o cuidado com o filho. Ao contrário, o envolvimento com a maternagem (função de cuidar e maternar) está relacionado a fatores sociais e culturais complexos, e principalmente com a disposição emocional da pessoa que se propõe a cuidar de uma criança, tal como fica expresso na frase de Mônica:

Trocava fralda e tudo. Ele ficava praticamente... porque ela trabalhava. Eu chegava mais cedo. Semprefuipegá- lo na crecheà tarde. Tanto éque un não podia sair porque ele só queria ficar comigo. Só comigo. Eu sentia que tinha que ajudar e dar carinho. Mas ele tem muita confiança em mim, né? Muitas coisas. Por exemplo, outro dia eu conversei com a mãe dele e disse que eles têm que sair mais sozinhos, que ela tem que participar mais da vida dele. Ele não aceita. Se ela vai ali e eu aqui, ele pergunta: Você vai voltar, tia Jô? Por exemplo, se ele está aqui e eu pego a bolsa pra sair. Ele quer saber aonde que eu vou, que horas que eu volto. Se eu falo que vou pra R., pelo amor de Deus, tem que ir escondido dele. Ele não aceita. A Joana, ele aceita. A mim, ele não aceita. Eu não sei por quê.

Vale ressaltar que Mônica apontou em alguns momentos da entrevista que nunca teve desejo de ser mãe e que sente não levar o menor jeito com crianças. Apesar disso, relata que todas as crianças de sua família (sobrinhos, afilhados) apegam-se a ela com muita facilidade, o que acredita ocorrer porque ela consegue compreendê-las em suas necessidades. Olhar para as necessidades da criança e compreendê-la enquanto alteridade, mais do que se confundir com ela, é o que estabelece o processo de humanização do bebê, conforme afirmam Aiello-Vaisberg e Granato (2006). Eé o que Mônica consegue realizar quando compreende o profundo terror que Pedrinho nos apresenta.

\section{Considerações Finais}

Diante do material exposto, parece ficar pre184 mente aquilo que Winnicott refere como a impossi- bilidade de algumas mães vivenciarem a regressão materna primária. No caso de Joana, por não ter podido contar com um ambiente emocional continente para suas próprias angústias, ela não pôde vivenciar na gravidez a preocupação materna primária, condição que prepara o cuidador para estabelecer uma comunicação sutil, porém intensa com o lactente. Conforme ela mesma revela, provavelmente a vivência da rejeição materna e a ausência de um ambiente continente às suas próprias angústias, dificultaram em grande parte o seu desenvolvimento. Além disso, a introjeção de uma figura masculina e paterna prejudicada e ausente contribuiu para que ela não conseguisse desenvolver plenamente sua experiência edípica.

Dessa maneira, pode-se afirmar que não é o fato de Joana viver uma escolha homoafetiva com Mônica que seria prejudicial ao desenvolvimento de Pedrinho, mas sim a qualidade precária dessa relação, que, conforme foi mostrado, não se apresenta sob a dinâmica de um casal parental que Pedrinho possa internalizar. Nesse sentido, este estudo defende que, muito mais do que julgar se um ambiente familiar é saudável ou não para o desenvolvimento de uma criança por conta da orientação sexual dos pais, o fundamental é compreender sua realidade intrínseca e a forma como seus membros se relacionam.

Também, nesse sentido, no caso em análise, a vivência da gravidez e da maternidade não constituiu, por si só, elemento preparatório para o estabelecimento de um bom vínculo com o bebê, mas significou mais a possibilidade de se angustiar diante de vivências tão intensas e de reviver as feridas narcísicas da mãe biológica. Por outro lado, Pedrinho pôde contar com a presença ativa e constante da "tia"Mônica que, mesmo não sendo sua mãe biológica, tem tentado funcionar como uma boa mãe de coração, e auxiliar a criança no processo de reparação das dificuldades de seu desenvolvimento.

Por fim, observações atentas diante de realidades tão diversas da família tradicional, embora cada vez mais presentes, só são possíveis graças ao aprofundamento apaixonado, respeitoso e continente dos valores alheios por parte do pesquisador, o que the permite se confrontar com o diferente e o novo, a fim de apreender os sentidos dessas novas experiências e realidades, que clamam cada vez mais por seu reconhecimento na sociedade pós-moderna. 


\section{Referências}

Aiello-Vaisberg, T. M., \& Granato, T. M. M. (2006). Ser e fazer: na clínica winnicottiana da maternidade. São Paulo: Idéias e Letras. (Coleção Psi-atualidades).

American Psychiatric Association. (1995). Manual diagnóstico e estatístico dos Distúrbios Mentais - DSM-VI (4a ed). Porto Alegre: Artes Médicas.

Badinter, E. (1985). Um amor conquistado: o mito do amor materno. Rio de Janeiro: Editora Nova Fronteira.

Bailey, J. M., Bobrow, D., Wolf, M., \& Mikach, S. (1995). Sexual orientation of adult son of gay fathers. Developmental Psychology, 31 (1), 124-129.

Durham, E. R. (1983). Perspectivas antropológicas da mulher. Rio de Janeiro: Zahar.

Granato, T. M. M. (2000). Encontros terapêuticos com gestantes à luz da preocupação materna primária. Dissertação de mestrado não-publicada, Instituto de Psicologia, Universidade de São Paulo.

Giovacchini, P. L. (1995). Interpretações, uma área técnica obscura. In Giovacchini, P. L. (Org.), Táticas e técnicas psicanalíticas D. W. Winnicott (pp.65-78). Porto Alegre: Artes Médicas.

Guiddens, A. (1993). A transformação da intimidade. São Paulo: Unesp.

Levi-Strauss, C. (1956). As organizações dualistas existem? In F. Boas. Antropologia estrutural. Rio de Janeiro: Editora Tempo Brasileiro.

Roudinesco, E. (2003). A família em desordem. Rio de Janeiro: Jorge Zahar.

Scavone, L. (2001). Motherhood: transformation in the family and in gender relations. Interface Comunicação Saúde e Educação, 5 (8), 47-60.

Silvertein, L. B., \& Auerbach, C. F. (1999). Deconstructing the essential father. American Psychologist, 6, 397-407.
Soifer, R. (1982). Psicodinamismos da família com crianças. Petrópolis: Vozes.

Stacey, J., \& Biblarz, T. J. (2001). (How) Does the sexual orientation of parent mother? American Sociological Review, 66, 159-183. Recuperado em abril 11, 2010, disponível em: <http://www.france.qrd.org/assocs/apgl/>.

Trinca, W. (1997). Formas de investigação clínica em psicologia: procedimentos de desenhos-histórias e procedimentos de desenhos de famílias com estórias. São Paulo: Vetor Editora Psico-Pedagógica.

Uziel, A. P. (2002). Família e homossexualidade: velhas questões, novos problemas. Tese de doutorado não-publicada, Programa de Pós-Graduação em Psicologia, Pontifícia Universidade Católica de Campinas.

Winnicott, D. W. (1975). A criatividade e suas origens. In D. W. Winnicott. O brincar e a realidade (p.95-120). Rio de Janeiro: Imago.

Winnicott, D. W. (1982). Um homem encara a maternidade. In D. W. Winnicott. A criançae o seu mundo (6a ed., p.15-18). Rio de Janeiro: Editora LTC. (Originalmente publicado em 1964).

Winnicott, D. W. (1983). Psicanálise do sentimento de culpa. In D. W. Winnicott. Oambientee os processos de maturação: estudos sobre a teoria do desenvolvimento emocional (pp.19-30). Porto Alegre: Artmed. (Originalmente publicado em 1958).

Winnicott, D. W. (1988). Pediatria e psiquiatria. In D. W., Winnicott. Textos selecionados: da pediatria à psicanálise (3a ed, pp.233-253). Rio de Janeiro: Francisco Alves.

Zambrano, E. (2006). Parentalidades "impensáveis": pais/mães homossexuais, travestis e transexuais. Horizontes Antropológicos, 12 (26), 123-147.

Recebido em: 16/9/2009

Aprovado em: 11/3/2011 
